\title{
Human immunonodeficiency virus, hepatitis $B$ virus and hepatitis $C$ virus: sero-prevalence, co-infection and risk factors among prison inmates in Nasarawa State, Nigeria
}

\author{
Moses P. Adoga ${ }^{1}$, Edmund B. Banwat ${ }^{2}$, Joseph C. Forbi ${ }^{1}$, Lohya Nimzing ${ }^{2}$, Christopher R. \\ $\mathrm{Pam}^{1}$, Silas D. Gyar ${ }^{4}$, Yusuf A. Agabi ${ }^{3}$, Simon M. Agwale ${ }^{1}$ \\ ${ }^{1}$ Virology Department, Innovative Biotech Ltd, 1 Abdu Abubakar Street, GRA, P.O.Box 30, Keffi, Nigeria \\ ${ }^{2}$ Department of Medical Microbiology, Faculty of Medical Sciences, University of Jos, \\ Nigeria \\ ${ }^{3}$ Department of Microbiology, Faculty of Natural Sciences, University of Jos, Nigeria \\ ${ }^{4}$ Department of Biological Sciences, Microbiology Unit, Faculty of Natural and Applied Sciences, Nasarawa State University, \\ Nigeria
}

\begin{abstract}
Background: Published data on HIV, HBV, and HCV in correctional facilities in Nigeria is scarce. We set out to establish the seroprevalence, co-infection, and risk factors for these infections for the first time among prison inmates in Nasarawa State, Nigeria.

Methodology: In a cross-sectional study conducted between April and May, 2007, blood samples were collected from 300 male prisoners of a mean age of 29.2 years, in the state's four medium-security prisons (overall population: 587). Prior to the study, ethical clearance and informed consent were obtained and structured questionnaires were administered. Samples were analyzed for HIV, HBsAg, and HCV using anti-HIV 1+2-EIA-avicenna, Shantest ${ }^{\mathrm{TM}}$-HBsAg ELISA, and anti-HCV-EIA-avicenna, respectively. Specimens initially reactive for HIV were retested with vironostika microelisa. Data were analyzed using SPSS version 13.0. P values $\leq 0.05$ were considered significant.

Results: Of the 300 subjects, 54 (18.0\%), 69 (23.0\%), and $37(12.3 \%)$ tested positive for HIV, HBV, and HCV, respectively. Co-infections were eight $(2.7 \%)$ for HIV/HBV and two $(0.7 \%)$ for HBV/HCV. Those aged 21-26 years were more likely to be infected with HIV and HBV, while those aged 33-38 years had the highest HCV infection. Associated risk factors included duration in prison, previous incarceration (for HIV, HBV and HCV), intra-prison anal sex, multiple sex partners (for HIV and HBV), ignorance of transmission modes, blood transfusion, and alcohol consumption (for HBV and HCV). No inmate injected drugs.

Conclusions: The overall outcome represents the need for prison-focused intervention initiatives in Nigeria. Injected drug use is an unlikely major transmission mode among Nigerian inmates.
\end{abstract}

Key Words: HIV, HBV, HCV, co-infection, risk factors

J Infect Dev Ctries 2009; 3(7):539-547.

Received 10 February 2009 - Accepted 28 May 2009

Copyright (C) 2009 Adoga et al. This is an open access article distributed under the Creative Commons Attribution License, which permits unrestricted use, distribution, and reproduction in any medium, provided the original work is properly cited.

\section{Introduction}

Unlike in Europe and America, there is a scarcity of published data on human immunodeficiency virus (HIV), hepatitis B virus (HBV), and hepatitis C virus (HCV) infections among prison inmates in Nigeria and the rest of Africa despite its tremendous importance in public health policy formulation. Prisons form part of the criminal justice system and it is estimated that over nine million people are in penal institutions worldwide, with 39,438 incarcerated in Nigeria as of January 31, 2007. The study area, Nasarawa State, housed 587 of these prisoners at the time of this study [1,2].

Compared with the non-incarcerated general population, prisoners worldwide continue to demonstrate a significantly higher prevalence of HIV, $\mathrm{HBV}$, and HCV infections [1,3]. These viruses are devastating disease agents of great public health concern and Africa suffers more than any other region. For instance, 39.5 million people are currently living with HIV/AIDS worldwide and almost 24.7 million $(63.0 \%)$ of these are in SubSaharan Africa [4]. In Nigeria, $4.4 \%$ of the population was infected with HIV in 2005, with an increase to $4.6 \%$ in 2008, while Nasarawa State had $6.7 \%$ of its population infected in 2005 with an alarming increase to $10 \%$ in 2008 [5].

$\mathrm{HBV}$ is the aetiological agent of hepatitis $\mathrm{B}$, a devastating liver disease. Globally, more than two billion people alive today have been infected with 
HBV at some time in their lives [6]. Of these, about 350 million have chronic infections and become carriers of the virus, and there are over four million acute clinical cases of HBV every year [6].

$\mathrm{HCV}$, on the other hand, is the principal cause of parenterally transmitted non-A, non-B hepatitis [7]. This blood-borne virus affects 200 million people worldwide, and an estimated $3.0 \%$ (170 million) of the world's population is chronically infected with $\mathrm{HCV}$ [8].

HIV, HBV, and HCV all have similar modes of transmission; however, $\mathrm{HCV}$ has low sexual transmission [8]. HBV is transmitted in the same way as HIV: by contact with blood or body fluids of an infected person, including perinatal, sexual contact, child-to-child transmission, unsafe injections, and transfusions; however, HBV is 50 to 100 times more infectious than HIV and 10 times more infectious than HCV [9].

The most efficient mode of transmission of $\mathrm{HCV}$ is direct percutaneous exposure to infectious blood [10]. Of persons newly infected with HCV, only $20.0 \%$ to $30.0 \%$ have symptoms of acute hepatitis, and the highest prevalence of $\mathrm{HCV}$ infection (70.0\% to $90.0 \%$ ) is reported among those persons with substantial or repeated direct percutaneous exposures to blood, such as intravenous drug users, persons with haemophilia treated with clotting factor concentrates that did not undergo viral inactivation, and recipients of transfusion from $\mathrm{HCV}$ - positive donors [10].

As in the case of HIV, there is currently no periodic national survey for $\mathrm{HBV}$ or $\mathrm{HCV}$ in either the Nigerian general population or prison inmates; however, prisoners worldwide are at high risk of contracting $\mathrm{HIV}, \mathrm{HBV}$, and $\mathrm{HCV}$, especially those who engage in high-risk behaviours such as injected drug use $[11,12]$. Prisoners are therefore potential reservoirs of infection to the uninfected entrants and the general non-incarcerated population upon regaining freedom.

We undertook a cross-sectional study in correctional institutions in Nasarawa State, Nigeria, to determine, for the first time, the seroprevalence, co-infection, and risk factors for these deadly infections.

\section{Materials and Methods}

Study Area

Nasarawa State has an area of $27,117 \mathrm{~km}^{2}$ and a population of $1,863,275$. It is bounded in the north by Kaduna State, the west by Abuja (the Nigerian capital city), the south by Kogi and Benue States, and the east by Taraba and and Plateau States. It is administratively divided into 13 Local Government Areas [13]. The state's prisons are located across the state in four different towns, namely Lafia, Wamba, Keffi, and Nasarawa. Lafia has a geo-coordinate of $8.49^{\circ} \mathrm{N}$ and $8.52^{\circ} \mathrm{E}$ and had an estimated population of 134,185 , Wamba has a geo-coordinate of $8.93^{\circ} \mathrm{N}$ and $8.60^{\circ} \mathrm{E}$ and had an estimated population of 28,096 , Keffi has a geo-coordinate of $8.84^{\circ} \mathrm{N}$ and $7.87^{\circ} \mathrm{E}$ and had an estimated population of 90,608 , and Nasarawa has a geo-coordinate of $8.52^{\circ} \mathrm{N}$ and $7.73^{\circ} \mathrm{E}$ and had an estimated population of 32,042 $[13,14]$.

\section{Study Population}

Three hundred prison inmates were recruited for this study from the four prisons in the state. A representative sample size was determined after having estimated the required minimum sample size using the formula propounded by Naing (2003) [15] at a $95 \%$ confidence interval.

\section{Ethical Consideration}

Clearance from the Ethical Committee in Nasarawa State's Ministry of Health was obtained in accordance with the code of ethics for biomedical research involving human subjects. Official consent of the state's highest prison authority-the state comptroller of prisons-was also obtained.

\section{Exclusion and Inclusion Criteria}

Prison inmates who were less than two months in detention were excluded from the study. All inmates who indicated willingness to participate in the study and gave written informed consent were included in the study.

\section{Specimen Collection}

Between April and May 2007, five millilitres of blood were aseptically collected from each prison inmate by venipuncture of the cubital vein using sterile disposable needles and syringes. Prior to the study, written informed consent was obtained, and socio-demographic and risk assessment information was collected on self-administered questionnaires. Samples were each placed in plain tubes and the sera separated into sample vials and stored at $-20^{\circ} \mathrm{C}$ until analyzed. 
Table 1. Age distribution of human immunodeficiency virus, hepatitis B surface antigen and hepatitis $\mathrm{C}$ virus among Nigerian prison inmates.

\begin{tabular}{ccccc}
\hline $\begin{array}{c}\text { Age } \\
\text { (Years) }\end{array}$ & № Tested (\%) & $H I V+(\%)$ & $H B s A g+(\%)$ & $H C V+(\%)$ \\
\hline $15-20$ & $30(10.0)$ & $4(13.3)$ & $3(10.0)$ & $2(6.7)$ \\
$21-26$ & $110(36.7)$ & $28(25.5)$ & $32(29.1)$ & $14(12.7)$ \\
$27-32$ & $87(29.0)$ & $14(16.1)$ & $21(24.1)$ & $13(14.9)$ \\
$33-38$ & $33(11.0)$ & $5(15.2)$ & $7(21.2)$ & $6(18.2)$ \\
$39-44$ & $15(5.0)$ & $2(13.3)$ & $3(20.0)$ & $1(6.7)$ \\
$45-50$ & $15(5.0)$ & $1(6.7)$ & $2(13.3)$ & $1(6.7)$ \\
$51-56$ & $10(3.3)$ & - & $1(10.0)$ & - \\
\hline Total & 300 & $54(18.0)$ & $69(23.0)$ & $37(12.3)$ \\
\hline
\end{tabular}

\section{Assay Procedure}

To detect anti-HIV, the anti-HIV1+2-EIAavicenna (Avicenna Medical Centre, Russia. Lot Number:05.45H) was initially used for screening. All reactive samples were retested with vironostika microelisa (Organon Teknika, USA), both according to each manufacturer's instructions. Shantest ${ }^{\mathrm{TM}}$ HBsAg ELISA (Shantha Biotechnics Limited, India. Lot number: DHB 01306) was used for the detection of HBsAg according to the manufacturer's instructions. The Shantest ${ }^{\mathrm{TM}}-\mathrm{HB}$ sAg ELISA is a sandwich enzyme immunoassay for the detection of $\mathrm{HBsAg}$ in human serum or plasma. Anti-HCV was detected using anti-HCV-EIA-avicenna (Lot number: 05.71C), also according to the manufacturer's instructions. Anti-HCV-EIA-avicenna is a qualitative enzyme immunoassay for the detection of antibodies to $\mathrm{HCV}$.

\section{Statistical Analysis}

Data were subjected to statistical analysis using the statistical software SPSS version 13.0. Pearson chi-squares were calculated at a 95\% confidence interval. $\mathrm{P}$ values $\leq 0.05$ were considered statistically significant.

\section{Results}

A total of 300 male prison inmates with the mean age of 29.2 years participated in the study. Fifty-four $(18.0 \%)$ were seropositive for HIV, 69
(23.0\%) for $\mathrm{HBsAg}$, and 37 (12.3\%) were $\mathrm{HCV}$ seropositive. Eight $(2.7 \%)$ were $\mathrm{HIV} / \mathrm{HBV}$ coinfected, and two $(0.7 \%)$ were co-infected with $\mathrm{HBV} / \mathrm{HCV}$. The age group of 21-26 years had the highest seroprevalence rate for HIV and HBV, while those aged 33-38 years had the highest infection of HCV (Table 1) $(\mathrm{P}>0.05)$. No inmate stated that he practiced injected drug use. Forty $(13.3 \%)$ had been incarcerated previously, $249(83.0 \%)$ did not have the correct knowledge of $\mathrm{HBV}$ and $\mathrm{HCV}$ transmission modes (tables 3 and 4), 32 (10.7\%) practiced anal sex (tables 2, 3, and 4), and $175(58.3 \%)$ had been in detention for more than six months (tables 2, 3, and 4). Thirty-seven (12.3\%) of the participants were from polygamous homes and $180(60.0 \%)$ habitually consumed alcohol before incarceration.

Figure 1 shows seroprevalence rates by prison location. Wamba Prison was the most affected by HIV (27.1\%) and HBV (35.7\%), followed by Lafia Prison $(\mathrm{HIV}=18.0 \%, \mathrm{HBV}=24.0 \%)$ and Keffi Prison $(\mathrm{HIV}=16.1 \%, \mathrm{HBV}=19.4 \%)$. Nasarawa Prison was the least affected (HIV $=10.3 \%$, HBV $=$ $11.1 \%)$. For HCV seroprevalence rates, Lafia Prison was highest with $16.0 \%$, followed by Keffi and Wamba Prisons with $12.9 \%$ and $10.0 \%$, respectively (figure 1). Inmates who stayed longer in prison and had been previously incarcerated were more likely to be infected with HIV, HBV, and HCV (tables 2, 3, and 4$)(P<0.05)$. Those who engaged in anal sex in prison and had multiple sex partners before incarceration were more likely to be infected with 


\section{Figure 1}

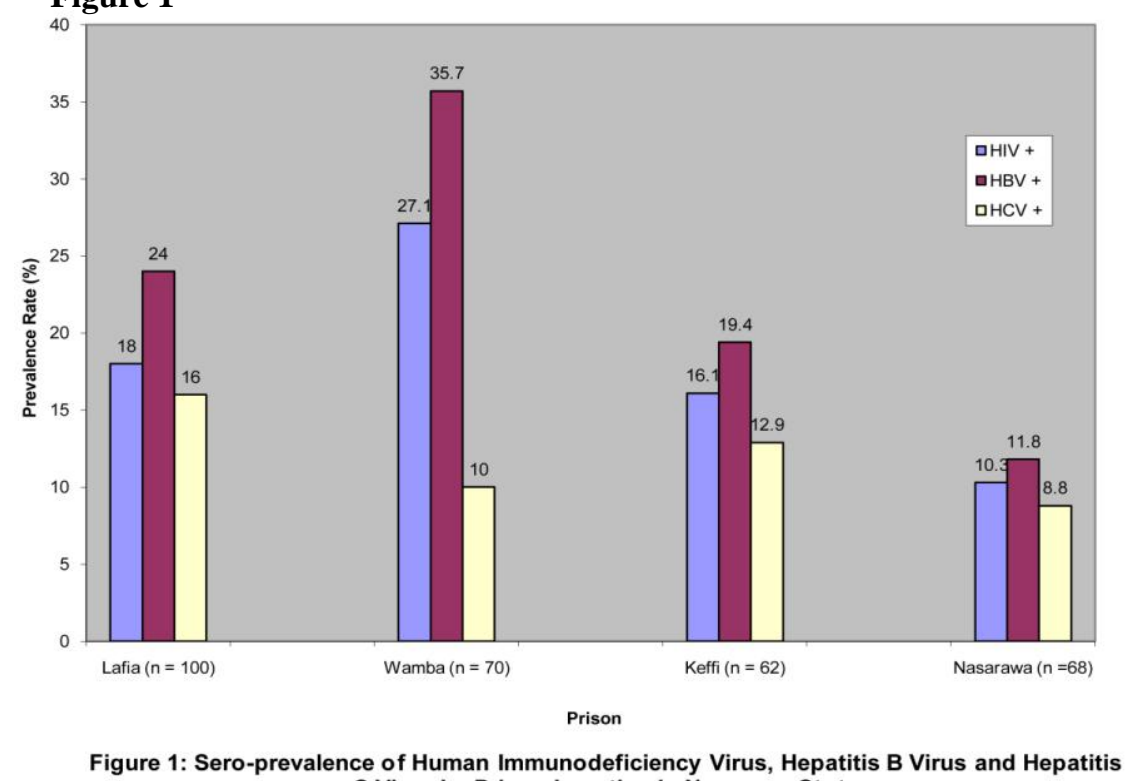

C Virus by Prison Location in Nasarawa State

HIV and HBV (tables 2 and 3) (P < 0.05), while histories of alcohol consumption and blood transfusion were significantly associated with $\mathrm{HBV}$ and HCV infections, respectively (tables 3 and 4) (P $<0.05)$. Those lacking the knowledge of HBV and $\mathrm{HCV}$ transmission modes were more likely to be infected with the two viral agents (tables 3 and 4) (P $<0.05)$.

\section{Discussion}

This study investigated the seroprevalence, coinfection, and risk factors for $\mathrm{HIV}, \mathrm{HBV}$, and $\mathrm{HCV}$ infections among prison inmates in Nigerian Nasarawa State. Such studies have been undertaken in a good number of countries, especially in Europe and America, yet reports on these viral agents among Nigerian prison inmates are scarce.

The high HIV, HBsAg, and HCV seroprevalence rates of $18.0 \%, 23.0 \%$, and $12.3 \%$, respectively, observed in this study are consistent with the similarly high $19.2 \%, 17.4 \%$, and $19.2 \%$ rates reported among prison inmates in Ghana [12], the slight differences notwithstanding. In accordance with our findings, some earlier studies have also reported high seroprevalence rates of $\mathrm{HIV}, \mathrm{HBV}$, and $\mathrm{HCV}$ among prison inmates. For instance, Macalino et al. (2004) reported HBV and HCV sero-prevalence rates of $20.2 \%$ and $23.1 \%$, respectively, in the US Rhode Island Prisons [16], and Burattini et al. (2000) reported $\mathrm{HIV}$ and $\mathrm{HCV}$ seroprevalence rates of $16.0 \%$ and $34.0 \%$, respectively, among Brazilian prisoners [17]; however, the HCV sero-prevalence rates from both studies are higher than what our study reveals, and this may be attributed to a possible practice of injected drug use by those inmates - a high-risk behaviour absent among our subjects. It should be noted, however, that although none of our subjects confirmed the practice of injected drug use, it is possible this probably happens among Nigerian prisoners but at a very minimal level, not enough to influence the outcome.

In contrast, Dada et al. (2006) reported a lower seroprevalence rate of $6.7 \%$ among male prisoners in Lagos, Nigeria [18]. This prevalence rate is startling because it is not higher than that of the general population of Lagos, even though the prisoner population is known to be a high-risk one; however, it is possible those inmates were well-informed and practiced preventive measures. We found it surprising that none of our subjects admitted to having ever injected drugs, going by reports that this is a common practice among inmates. [11,16,17]. This is consistent with the assertion by Madhava et al. (2002) that injected drug use is infrequent in subSaharan Africa [8]; however, injected drug use has been implicated as a major risk behaviour for HIV, $\mathrm{HBV}$, or HCV transmission among prison inmates, especially in countries outside of Africa [1,19,20], with prevalence for HIV and HCV among a Russian population of injected drug users reaching as high as $56.0 \%$ and $87.0 \%$, respectively [21]. Based on our conversation with the prison officers, a drug habit common among Nigerian inmates is that of smoking wiwi which is never injected. Future studies should find the association of this with infections. 
Table 2. Seroprevalence of human immunodeficiency virus by risk factors among prison inmates in Nasarawa State.

\begin{tabular}{|c|c|c|c|c|c|}
\hline Risk Factor & № Tested & HIV Positive & \multicolumn{2}{|c|}{$\%$ Positive $\chi^{2}$} & P Value \\
\hline \multicolumn{6}{|c|}{ Duration in Prison } \\
\hline$\leq 6$ months & 125 & 12 & 9.6 & 9.29 & 0.00 \\
\hline$>6$ months & 175 & 42 & 24.0 & & \\
\hline \multicolumn{6}{|c|}{ Alcohol Consumption } \\
\hline Yes & 180 & 32 & 17.8 & 0.02 & 0.90 \\
\hline No & 120 & 22 & 18.3 & & \\
\hline \multicolumn{6}{|c|}{ № of Sex Partners } \\
\hline 1 & 99 & 12 & 12.1 & & \\
\hline 2 & 120 & 20 & 16.7 & 7.07 & 0.03 \\
\hline$\geq 3$ & 81 & 22 & 27.2 & & \\
\hline \multicolumn{6}{|l|}{ Anal Sex } \\
\hline Yes & 32 & 14 & 43.8 & 14.20 & 0.00 \\
\hline No & 268 & 40 & 14.9 & & \\
\hline \multicolumn{6}{|c|}{ Blood Transfusion } \\
\hline Yes & 8 & 3 & 37.5 & 0.98 & 0.32 \\
\hline No & 292 & 51 & 17.5 & & \\
\hline \multicolumn{6}{|l|}{ Tribal Marks } \\
\hline Yes & 36 & 2 & 5.6 & 4.29 & 0.04 \\
\hline No & 264 & 52 & 19.7 & & \\
\hline \multicolumn{6}{|c|}{ Previous Incarceration } \\
\hline Yes & 40 & 13 & 32.5 & 5.49 & 0.02 \\
\hline No & 260 & 41 & 15.8 & & \\
\hline \multicolumn{6}{|c|}{ Family Background } \\
\hline Polygamous & 37 & 6 & 16.2 & & \\
\hline Monogamous & 263 & 48 & 18.3 & 0.01 & 0.94 \\
\hline
\end{tabular}

Table 3. Seroprevalence of hepatitis B virus by risk factors among prison inmates in Nasarawa State.

\begin{tabular}{|c|c|c|c|c|c|}
\hline Risk Factor & № Tested & HBs $A$ & ve $\% \mathrm{P}$ & ve $\chi^{2}$ & P Value \\
\hline$\leq 6$ months & 125 & 18 & 14.1 & 8.14 & 0.00 \\
\hline$>6$ months & 175 & 51 & 29.1 & & \\
\hline \multicolumn{6}{|c|}{ Alcohol Consumption } \\
\hline Yes & 180 & 52 & 28.9 & 8.00 & 0.00 \\
\hline No & 120 & 17 & 14.2 & & \\
\hline \multicolumn{6}{|c|}{ № of Sex Partners } \\
\hline 1 & 99 & 15 & 15.2 & 9.68 & 0.00 \\
\hline 2 & 120 & 26 & 21.7 & & \\
\hline$\geq 3$ & 81 & 28 & 34.6 & & \\
\hline \multicolumn{6}{|l|}{ Anal Sex } \\
\hline Yes & 32 & 18 & 56.3 & 20.31 & 0.00 \\
\hline No & 268 & 51 & 19.0 & & \\
\hline \multicolumn{6}{|c|}{ Blood Transfusion } \\
\hline Yes & 8 & 2 & 25.0 & 0.02 & 0.89 \\
\hline No & 295 & 67 & 22.9 & & \\
\hline \multicolumn{6}{|l|}{ Tribal Marks } \\
\hline Yes & 36 & 4 & 11.1 & 3.27 & 0.07 \\
\hline No & 264 & 65 & 24.6 & & \\
\hline \multicolumn{6}{|c|}{ Previous Incarceration } \\
\hline Yes & 40 & 6 & 11.8 & 4.38 & 0.03 \\
\hline No & 260 & 63 & 25.3 & & \\
\hline \multicolumn{6}{|c|}{ Transmission modes' knowledge } \\
\hline Yes & 51 & 16 & 40.0 & 6.47 & 0.01 \\
\hline No & 249 & 53 & 20.4 & & \\
\hline \multicolumn{6}{|c|}{ Family Background } \\
\hline Polygamous & 37 & 10 & 27.0 & 0.17 & 0.68 \\
\hline Monogamous & 263 & 59 & 22.4 & & \\
\hline
\end{tabular}


Table 4: Seroprevalence of Hepatitis C virus by risk factors among prison inmates in Nasarawa State

\begin{tabular}{|c|c|c|c|c|c|}
\hline Risk Factor & № Tested & HCV Positive & \% Positiv & $\chi^{2}$ & Value \\
\hline$\leq 6$ months & 125 & 8 & 6.4 & 6.07 & 0.01 \\
\hline$>6$ months & 175 & 29 & 16.6 & & \\
\hline \multicolumn{6}{|c|}{ Alcohol Consumption } \\
\hline Yes & 180 & 22 & 12.2 & 0.01 & 0.94 \\
\hline No & 120 & 15 & 12.5 & & \\
\hline \multicolumn{6}{|c|}{ № of Sex Partners } \\
\hline 1 & 99 & 13 & 13.1 & 0.17 & 0.92 \\
\hline 2 & 120 & 15 & 12.5 & & \\
\hline$\geq 3$ & 81 & 9 & 11.1 & & \\
\hline \multicolumn{6}{|l|}{ Anal Sex } \\
\hline Yes & 32 & 4 & 12.5 & 0.00 & 0.98 \\
\hline No & 268 & 33 & 12.3 & & \\
\hline \multicolumn{6}{|c|}{ Blood Transfusion } \\
\hline Yes & 8 & 3 & 37.5 & 4.82 & 0.03 \\
\hline No & 295 & 34 & 11.6 & & \\
\hline \multicolumn{6}{|l|}{ Tribal Marks } \\
\hline Yes & 36 & 1 & 2.8 & 3.46 & 0.06 \\
\hline No & 264 & 36 & 13.6 & & \\
\hline \multicolumn{6}{|c|}{ Previous Incarceration } \\
\hline Yes & 40 & 14 & 3.9 & 4.02 & 0.05 \\
\hline No & 260 & 23 & 14.1 & & \\
\hline \multicolumn{6}{|c|}{ Transmission modes' knowledge } \\
\hline Yes & 51 & 2 & 35.0 & 19.58 & 0.00 \\
\hline No & 249 & 35 & 8.8 & & \\
\hline \multicolumn{6}{|c|}{ Family Background } \\
\hline Polygamous & 37 & 4 & 10.8 & 0.00 & 0.97 \\
\hline Monogamous & 263 & 33 & 12.5 & & \\
\hline
\end{tabular}

Our findings reveal much higher HIV, HBV, and $\mathrm{HCV}$ infection rates than those observed in the general population. For instance, the Nigerian national HIV/syphilis sentinel survey among women attending antenatal clinics (a similar national survey for men has not yet been performed) shows that $6.7 \%$ of the general population of Nasarawa State were infected with HIV/AIDS at about the time our study was conducted, and $10 \%$ had the infection in 2008 [5]. Although no such periodic national survey exists for $\mathrm{HBV}$ or $\mathrm{HCV}$, available data outside of Nasarawa State show much lower seroprevalence rates among non-incarcerated populations [8,22-27].

The $2.7 \%$ HIV/HBV co-infection rate observed in this study is higher than the $1.0 \%$ reported by Baba et al. (2000) in a population of blood donors in Nigeria [23] for an obvious reason: prison inmates are a high-risk group; however, it is lower than the $24.7 \%$ or $28.2 \%$ HIV/HBV co-infection rate reported by Mustapha and Jibrin (2004) among a population of HIV/AIDS patients in Nigeria [27]. The already compromised immune mechanisms of the HIV/AIDS patient population should be responsible for their higher chances of co-infection with HBV. The coinfection observed in this study is instructive since it has been reported that co-infection of HIV with HBV or $\mathrm{HCV}$ increases the risk for hepatotoxicity of highly active antiretroviral therapy (HAART) regimen in HIV/AIDS patients, and HCV coinfection results in attenuated CD4 recovery after initiation of HAART [28]. We did not find either $\mathrm{HIV} / \mathrm{HCV}$ or HIV/HBV/HCV co-infection; however, this has been reported among prison inmates [29] and HIV-infected populations [28,30,31].

When we compared prevalence rates in the four prisons, inmates in Wamba prison were more likelyto be infected with HIV and HBV while those in Lafia prison were more likely to be infected with $\mathrm{HCV}$, but the differences did not reach statistical significance. 
We found that prison inmates within the age group of 21-26 years were more likely to be infected with HIV and $\mathrm{HBV}$, and this corresponds with earlier reports in Nigeria [18,23], while inmates aged between 33 and 38 years were more likely to be infected with HCV. This is also in accord with previous findings in the Nigerian Niger Delta and Australia [11,26]. Although blood transfusion was significantly associated with HCV infection, studying a larger number of subjects who have received transfused blood will give a clearer picture. In spite of government policy on blood transfusion, some suburban and rural clinical centres screen potential donors for HIV and only manage to screen for HBV (leaving out HCV); hence the association of blood transfusions with $\mathrm{HCV}$ is not surprising.

Our discovery that duration in prison and previous incarceration were significantly associated the infections of HIV, HBV, and HCV is consistent with reports from Australia, Brazil, Italy, England, and Wales [11,17,32,33]. There was a higher percentage of infection with the three agents among inmates who had no tribal marks than those who had, with HIV infection being significant (table 2) and with HBV and HCV approaching significance (tables 3 and 4). This observation shows that having tribal marks was not a risk factor among the study subjects; however, this may not be a perfect conclusion because the marks are usually given early in life, and considering the mean age of the subjects, those who might have contracted infection through such means should have died, especially of HIV, before incarceration. We therefore recommend a study involving a larger sample size of people with tribal marks for a better understanding of its association with these infections. The significant association of intra-prison anal sex and multiple sex partners with HIV and HBV infections also finds support in previous reports from Italy and African countries $[1,12,33]$.

We also discovered that histories of alcohol consumption and blood transfusion were significantly associated with HBV and HCV infections, respectively. This observation corresponds with previous findings $[10,34,35]$. The poor knowledge of HBV and HCV transmission modes among the inmates, which made those without the knowledge to be more likely to be infected with the two viral agents, is consistent with the study by Butler et al. (1997) who reported that there was poor knowledge of hepatitis risk factors among their study subjects
[20]. The congested nature of the prisons - from prison records, most of the prisons housed inmates above their official capacity - might be an important factor in the transmission of the hepatitis viruses. There should be a Nigerian government policy that makes it compulsory for all prisoners to be tested prior to incarceration for hepatitis viruses and vaccinated against vaccine preventable diseases. This practice will control the spread of infections within prisons and within the general public upon an inmate's regaining freedom.

Our results show higher infection rates than the reports in the non-incarcerated general population. This represents an important public health issue. Since inmates are potential reservoirs of infection to the public upon release, they should be tested for possible infectious diseases and treated before continuing their normal public lives. Considering the potential of such a study to serve as the basis for better strategies towards controlling the spread of deadly viral infections, we recommend an incidence study that will involve more prisons from the remaining states of Nigeria. Although some factors identified in this study, such as duration in prison, anal sex, previous incarceration history, and lack of knowledge of the modes of transmission, can be said to have contributed to infections in the prisons, we recommend a study that focuses on identifying more intra-prison factors involved in transmission (since this study was a bit limited in that respect), because this will give a truer national picture of the alarming situation. To succeed, Nigerian treatment services and general prevention efforts, including vaccination and risk minimization measures, must include prison inmates.

\section{Acknowledgements}

We are indebted to Dr. (Ms) Sheyin Nenadi, DCP (Mrs.) Akwashiki and Ms Chinwe Agupugo for their assistance. We thank Innovative Biotech for being the major sponsor of this work.

\section{References}

1. Senok AC, Botta GA (2006) Human immunodeficiency virus and hepatitis virus infection in correctional institutions in Africa: is this the neglected source of an epidemic? Journal of Medical Microbiology 55:481-482.

2. International Centre for prison studies (2007) World Prison Population. Available: www.highbeam.com/doc/IGI. Accessed 27 December.

3. Weinbaum CM, Sabin KM, Santibanez SS (2005) Hepatitis $\mathrm{B}$, hepatitis C, and HIV in correctional population: a review of epidemiology and prevention. AIDS 19: S41-S46. 
4. UNAIDS/WHO (2007) AIDS epidemic update. Available: www.unaids.org. Accessed 7 September.

5. Federal Ministry of Health, Nigeria (2008) A technical report on the national HIV/Syphilis sero-prevalence sentinel survey in Nigeria.

6. World Health Organisation (2007) Hepatitis B Fact Sheet N²04. Available: http://www.who.int/csr/disease/hepatitis. Accessed 20 September.

7. Strickland GT (2002) Hepatitis C in developing countries. Infectious Diseases 24: 26-28.

8. Madhava V, Burgess C, Drucker E (2002) Epidemiology of chronic hepatitis $\mathrm{C}$ virus infection in Sub-saharan Africa. Lancet Infectious Diseases 2: 293-302.

9. CDC (2001) Updated U.S. Public Health Service guidelines for the management of occupational exposures to HBV, $\mathrm{HCV}$, and $\mathrm{HIV}$ and recommendations for post exposure prophylaxis. MMWR 50 (RR-11): 1-42.

10. CDC (2003) Prevention and control of infections with hepatitis viruses in correctional settings. MMWR 52(RR-1): 1-36.

11. Butler T, Boonwat L, Hailstone S, Falconer T, Lems P, Ginley T, Read V, Smith N, Levy M, Dore G, Kaldor J (2007) The 2004 Australian prison entrants' blood-borne virus and risk behaviour survey. Australian and New Zealand Journal of Public Health 31: 44-50.

12. Adjei AA, Armah HB, Gbagbo F, Ampofo WK, Quaye IKE, Hesse IFA, Mensah G (2006) Prevalence of human immunodeficiency virus, hepatitis B virus, hepatitis $\mathrm{C}$ virus and syphilis among prison inmates and officers at Nsawam and Accra, Ghana. Journal of Medical Microbiology 55: 593-597.

13. Wikipedia, the free encyclopedia (2007) Geography of Nasarawa State. Available: http://en.wikipedia.org/wiki/Nasarawa_State. Accessed 10 October.

14. World Gazetteer (2007) Geography of Nigeria. Available: www.world-gazetteer.com. Accessed October 10.

15. Naing NN (2003) Determination of sample size. Malaysian Journal of Medical Sciences 10: 84-86.

16. Macalino GE, Vlohov D, Sanford-Colby S, Patel S, Sabin K, Salas C, Rich JD (2004) Prevalence and incidence of HIV, hepatitis B virus, and hepatitis C virus infections among males in Rhode Island prisons. American Journal of Public Health 94: 1218-1223.

17. Burattini M, Massad E, Rozman M, Azevedo R, Carvalho H (2000) Correlation between HIV and HCV in Brazilian Prisoners: evidence for parenteral transmission inside prison. Revista de saude publica 34: 431-436.

18. Dada MO, Akanmu AS, Esan OA (2006) Seroprevalence of HIV among male prisoners in Lagos State, Nigeria. Nigerian Postgraduate Medical Journal 13: 6-9.

19. Rhodes T, Platt L, Maximova M, Renton A, Bobrova N, McDonald T, Parry JV (2006) Prevalence of HIV, hepatitis $\mathrm{C}$ and syphilis among injecting drug users in Russia: a multi-city study. Addiction 101: 252-266.

20. Butler JG, Dolan KA, Ferson MJ, McGuinness LM, Brown PR, Robertson PW (1997) Hepatitis B and C in New South Wales Prisons: prevalence and risk factors. Medical Journal of Australia 166: 127.

21. Rhodes T, Platt L, Judd A, Mikhailova L.A, Sarany A, Wallis N, Alpatova T, Hickman M, Parry JV (2005) Hepatitis $\mathrm{C}$ virus infection, HIV co-infection and associated risk among injecting drug users in Togliatti, Russia. International Journal of STD and AIDS 16: 749-754.
22. Egah DZ, Mandong BM, Iya D, Gomwalk NE, Audu ES, Banwat EB, Onile BA (2004) Hepatitis C virus antibodies among blood donors in Jos, Nigeria. Annals of African Medicine 3: 35-37.

23. Baba MM, Hassan AW, Gashauw W (2000) Prevalence of hepatitis A antigenemia and human immunodeficiency virus in blood donors in Maiduguri, Nigeria. Nigerian Journal of Medicine 9: 10-12.

24. Koate BB, Buseri FF, Jeremiah ZA (2005) Seroprevalence of hepatitis $\mathrm{C}$ among blood donors in Rivers State, Nigeria. Transfusion Medicine 15: 449-451.

25. Erhabor O, Ejele OA, Nwauche CA (2006) The risk of transfusion-acquired hepatitis $\mathrm{C}$ virus infection among blood donors in Port Harcourt: the question of blood safety in Nigeria. Nigeria Journal of Clinical Practice 9: 18-21.

26. Ejele OA, Nwauche CA, Erhabor O (2006) Seroprevalence of hepatitis $\mathrm{C}$ in the Niger Delta of Nigeria. Nigeria Postgraduate Medical Journal 13: 103-106.

27. Mustapha SK, Jibrin YB (2004) The prevalence of hepatitis $B$ surface antigenaemia in patients with human immunodeficiency virus (HIV) infection in Gombe, Nigeria. Annals of African Medicine 3: 10-12.

28. Forbi JC, Gabadi S, Alabi R, Iperepolu HO, Pam CR, Entonu PE, Agwale SM (2007) The role of triple infection with hepatitis $\mathrm{B}$ virus, hepatitis $\mathrm{C}$ virus and human immunodeficiency virus type- 1 on $\mathrm{CD}^{+}$lymphocyte levels in the highly infected population of North-Central Nigeria. Memorias do Instituto Oswaldo Cruz 102: 535-537.

29. Saiz de la Hoya P, Bedia M, Murcia J, Sanchezpaya J, Portilla J (2005) Predictive markers of HIV and HCV infection and co-infection among inmates in a spanish prison. Enfermedades Infecciosas Microbiologia Clinica 23: 53-57.

30. Agwale SM, Tanimoto L, Womack C, Odama L, Leung K, Dubey D, Negedu-Momola R, Audu I, Mohammed SB, Inyang U, Graham B, Ziermann R (2004) Prevalence of $\mathrm{HCV}$ coinfection in HIV-infected individuals in Nigeria and characterization of $\mathrm{HCV}$ genotypes. Journal of Clinical Virology 31S: S3-S6.

31. Nimzing L, Lar PM, Nimchak KG, Daru PH (2006) Prevalence of anti-hepatitis $\mathrm{C}$ antibody in HIV-1 positive pregnant women in Jos. Journal of Medicine in the Tropics 8: $1-7$.

32. Weild AR, Gill ON, Bennett D, Livingstone SJ, Parry JV, Curran L (2000) Prevalence of HIV, hepatitis B, and hepatitis $\mathrm{C}$ antibodies in prisoners in England and Wales: a national survey. Communicable Disease and Public Health 3: 121-126.

33. Babudieri S, Longo B, Sarmati L, Starnini G, Dori L, Suligoi B, Carbonara S, Monarca R, Quercia G, Florenzano G, Novati S, Sardu A, Iovinella V, Casti A, Romano A, Vecella I, Maida I, Brunett B, Mura MS, Andreoni M, Rezza G (2005) Correlates of HIV, HBV, and HCV infections in a prison inmate population: results from a multicentre study in Italy. Journal of Medical Virology 76: 311-317.

34. CDC (2007) Epidemiology and prevention of hepatitis A-E: an overview. Available: www.cdc.gov/hepatitis. Accessed 7 September 2007.

35. Imarengiaye CO, Enosolease ME, Iribhogbe PE, Ehigiegba AE (2006) Risk of transfusion transmitted hepatitis $C$ virus in a tertiary hospital in Nigeria. Public Health 120: 274-278. 


\section{Corresponding author}

Moses P. Adoga

Address: Innovative Biotech

Conflict of interest: No conflict of interest is declared.

POBox 30, Keffi, Nasarawa State, Nigeria

Phone: +2348036248498

Email: madoga@innovativebiotechng.com

adogamoses@yahoo.com 